\title{
静水圧押出しにおけるスティックスリップ*
}

\author{
久 保 勝 司**

\section{Prevention of Stick-Slip Motion in Hydrostatic Extrusion of Billet} \\ by
}

Katsushi KuBO

(Government Industrial Research Institute, Nagoya, Nagoya)

The hydrostatic extrusion of the billet is a new extrusion process differing from the conventional method in utilizing the pressurized liquid and keeping the material in contact with the dies. The practical use of this process involves a serious question concerning how to prevent the stickslip motion. There are, it is considered, various factors that bring about the stick-slip motion, such as lubricants, extrusion ratios, the materials of the billet and die angles. In the present study the stick-slip motion has been analyzed in terms of these factors using an electromagnetic oscillograph. The results obtained are as follows.

(1) The temperature of oil film of lubricant formed inside the dies holding the billet plays an important part in causing the stick-slip motion.

(2) The smaller die angle will render the lubricant to be preventive of the stick-slip motion.

(3) Large stick-slip motion has always appeared with bulging deformation at the extrusion of brittle materials.

(Received Apr. 2, 1971)

\section{1 緒言}

静水圧押出し法は高圧力媒体液を介してビレットを 押出すために, ビレットとコンテナ間の摩擦はなく， また，ビレットとダイとの摩擦係数も小さい。したが って静水圧押出し法は従来のラム押出し法に比べて， (1)押出し压力が小さい（2)均一な材料の流れが得られ る（3）長い素材の押出しができる (4)素材の断面形状 は自由であるなどの長所を持っている。

静水圧押出しに抢いては，押出し荷重が周期的な振 動を起こすことがある゙。の現象はステイックスリッ プ (stick-slip) 之呼ば䄇水圧押出し法の欠点の一つ である.押出乙時にステイックスリップが発生すると, 押出し材表面には損傷が起こるし，工具は必要以上の 応力を繰り返し受けるので工具寿命は短くなる。この ように, 静水圧押出しのさいステイックスリップが発 生すると加工に悪い影響を与えるが，ステイックスリ ップの発生に肪よ淁す押出し条件の影響はあまり知ら れていない。

さて, スライダーと台とのすべり摩擦の研究によれ ば，材料が二面間ですべり運動をする場合に，静摩擦 係数と動摩擦係数の大きさに違いがあり, その運動系 が弾性自由度を有するとステイックスリップが発生す

* 原稿受理 昭和 46 年 4 月 2 日

** 正 会 員 名古屋工業技術試験所 名古屋市北区平手町
ることが明らかにされている。

本報告は, 静水圧押出しのさい発生するステイッ クスリップを防止するのを目的として，ステイックス リップに拉よぼすダイ角度, 押出し比, ビレット材料, 潤滑剤の影響を調べたものである。

\section{2 実験装置と方法}

\section{$2 \cdot 1$ 静水圧押出し装置および圧力媒体}

Fig. 1 亿静水圧押出乙装置の概略を示す。プランジ ヤ先端部技よびダイ下部の圧カシールは, リン青銅製 のマイタリングとネオプレン製の○ーリングを組み合 わせて行なった。押出し用円錐ダイ (1) はダイス鋼 （SKD-11）を燒入れ焼もどし処理後研摩してあり，硬 度は $\mathrm{H}_{\mathrm{R}} \mathrm{C} 52 \sim 55$, 表面あらさは $H_{\max } 0.4 \sim 0.8 \mu$ であ る。使用したダイの半角 $\alpha$ は $7.5^{\circ}, 15^{\circ}, 22.5^{\circ}, 30^{\circ}$, $45^{\circ}$ の 5 種類で, 出口直径梳いずれも $15 \mathrm{~mm}$ である. ダイ出口の角は微少な丸みをつけてあるが，ランドは 設けてない。

プランジャに負荷するとビレット(2)は圧力媒体液(4) を介して押出される。な掠，負荷中のプランジャの平 均速度は約 $0.7 \mathrm{~cm} /$ 秒である. ダイ半角が $30^{\circ}$ 以上の 場合にはカイド(3)を使用してビレットがなるべく垂直 に押出されるようにした。

本実験で圧力媒体として主に使用したモータ油は, 内燃機関用の潤滑油として一般に使用されているもの 


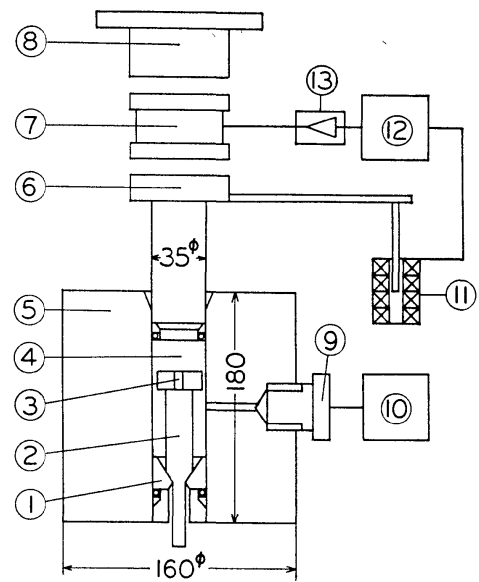
(1) Die
(3) Guide
(2) Billet
(5) Pressure cell
(4) Pressure medium
(7) Load cell
(6) Plunger
(9) Manganin pressure gage
(11) Displacement meter
(8) Press
(10) Recorder
(12) $\mathrm{X}-\mathrm{Y}$ recorder
(13) Strain meter

Fig. 1. A sketch of hydrostatic extrusion apparatus.

で, 潤滑効果を向上させるために鉱油に, 主として清 浄剂, 酸化防止材, 極圧剂, 油性剂などの添加剂が添 加されている。したがって, 塑性加工用の潤滑剤とし ても有効であるが, 別に添加する潤滑剂として, 二硫 化モリブデンおよび黒鉛潤滑剂（商品名ダイルーブ） を用意し，これをダイとビレットに塗布してとれらの 効果を調べた。

\section{$2 \cdot 2$ 押出し圧力の測定}

押出し圧力の測定はひずみゲージを貼ったロードセ ル(7)でプランジャ荷重を計測する方法を主に用いた。 そして, 補助的にマンガニン圧力計(9)を用いて, 押出 乙圧力の時間的変化を求めた。この場合，巨視的な圧 力変化を記録するのに自動平衡式 2 ペンレコーダーを， 微視的な変化を記録するには電磁オッシログラフを用 いた。

\section{$2 \cdot 3$ 供試材料と試験片形状}

供試材料は工業用純了ルミニウム（A1 B1），7一 3 黄銅の各引抜棒とアルミニウム合金鋳物 (A C 2 B ) および亜鉛合金鋳物（ZnADC1）の棒材である.

ラム押出し法において，ビレット先端の形状は押出 し圧力に影響を与觉ることが知られている。 つまり, ビレット先端部分がノーズをもたない平端面であった り，ノーズが短いと押出し始めに拈いてビレットとダ イ面間に局部的に大きな応力が発生して潤滑膜の破断 を引き起こし，押出し初期に圧力こぶを作る原因とな る.とこで，本実験に用いた試験片はFig. 2 に示すよ ろに，旋削加工により任意の直径にしたあと，ダイ円 錐部分にちようどはまるノーズを設けて，圧力こぶの

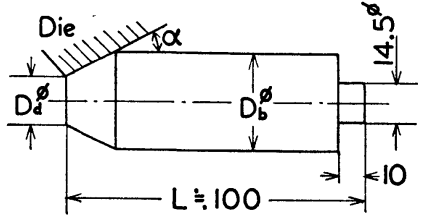

Fig. 2. Dimensions of billet.

発生を防ぐようにした。試験片の表面あらさは $H_{\max }$ で $2 \mu \sim 3 \mu$ であり，熱処理はしてない。ここで押出 し比Rはダイの出口寸法を $D_{d}$, ビレットの直径を $D_{b}$ とすれば, $R=\left(D_{b} / D_{d}\right)^{2}$ で表わされる.

\section{3 実 験 結 果}

\section{$3 \cdot 1$ 静水圧押出しにおけるスティックスリップの 特徵}

Fig. 3 はステイックスリップが発生したときの押出 乙圧力の変動を巨視的に示す一例である.Fig. 3 に示 すよ5に, 静水圧押出しに打忖るステイックスリップ はバルジ変形によって起こる場合 (Fig. 3 の(a)) と, ダイとビレット間の潤滑性によって起こる場合 (Fig. 3 の(b)）とに大別できる. 後述するように, 後者の場 合はダイ表面とビレットは境界摩擦状態にあると考觉 られる。バルジ変形を伴う場合は, (b)の場合に比べて 激しいステイックスリップが起こる.このように，押 出し時にステイックスリップが起こると, 押出し圧力 が周期的な振動を行なうとともに，コーン，コーンと い5摩擦音を伴うのが大きな特徽である。一方，押出 し材表面には円環状のストップマークができるが，こ の数は押出し線図に現われている振動数と一致する.

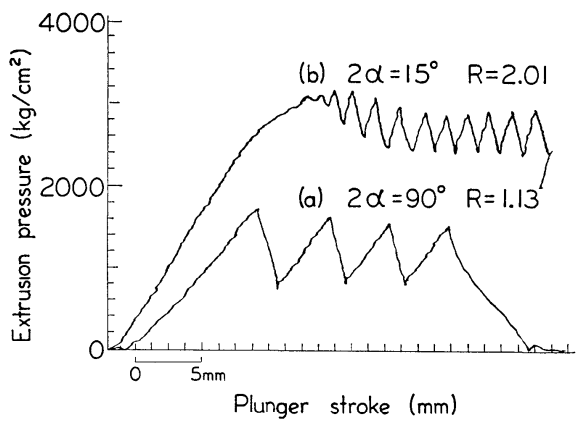

Fig. 3. Pressure diagram for $A C 2 B$ showing "stickslip motion".

上述したように，ステイックスリップが起こると押 出し圧力が凬期的に変動するので，以後に拉いてはこ の圧力の振幅の大きさ $\Delta p_{f}$ を fluctuation pressure と 呼んでステイックスリップの大きさを表わす尺度とし て用いる。

\section{$3 \cdot 2$ バルジ変形に起因するスティックスリップ}

Fig. 4 に大きなダイ角度のさいに起こるステイック スリップの大ささを示す．この場合 $\mathrm{AC} 2 \mathrm{~B}$ を除けば 
ステイックスリップが起こる押出し比の範困は小さく て、いずれも押出し比が小さい所でバルジ変形を伴

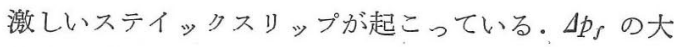
きさは材料によって異なるが，バルジ変形を伴うステ イックスリップが消滅する押出し比 $R_{B}$ は注ぼ同じで 西る( $R_{B}$ は約 1.3)。ただ $\mathrm{AC} 2 \mathrm{~B}$ はバルジ変形がなく なった後でもステイックスリップが起こっている。乙 かし, 同じアルミニウム系でも A 1 B 1 の場合, バル ジ変形は起こっているが，ステイックスリップは生じ ない。

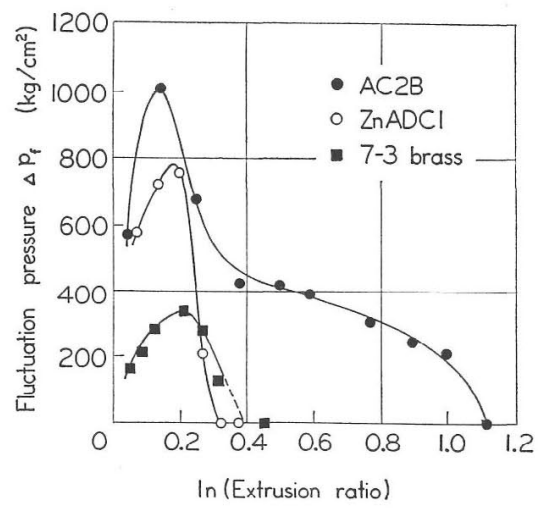

Fig. 4. Variation of fluctuation pressure of stickslip motion with extrusion ratio for $45^{\circ}$ semicone angle die.

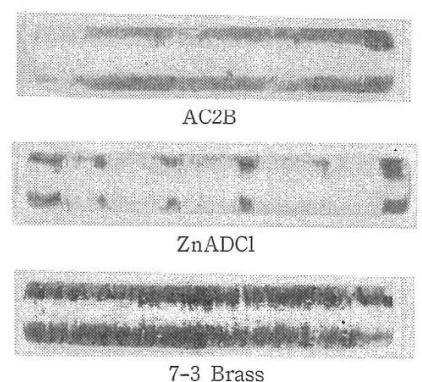

7-3 Brass

Fig. 5. Photograph of extruded materials with stickslip motion caused by buldge formation.

Fig. 5 はバルジ変形を起こしたときの押出し材の写 真で，材料による表面損傷の違いを走す代表例である。 黄銅にくらべると, $\mathrm{AC} 2 \mathrm{~B}$ 㱐よび $\mathrm{ZnADC1}$ は周期的

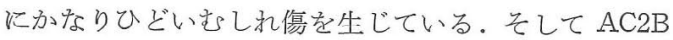
の場合は, バルジ変形の発生に対応してダイの出口近 傍表面に約 2 3 mm の幅で材料の固着が生じている。

\section{$3 \cdot 3$ ダイ角度と押出し比の影響}

Fig. 6 に $\mathrm{AC} 2 \mathrm{~B}$ の $\Delta p_{j}$ に拉よぼすダイ角度と押出 し比の影響を示す. 押出し比が約 $3(\ln R=1.1)$ 以上 になると,いずれの場合も，定常押出し中にはステイ ックスリップは起こらなくなる。一方押出し比が 3 以 下の場合， $\Delta p_{j}$ はダイ角度の影響を受けるが，特に

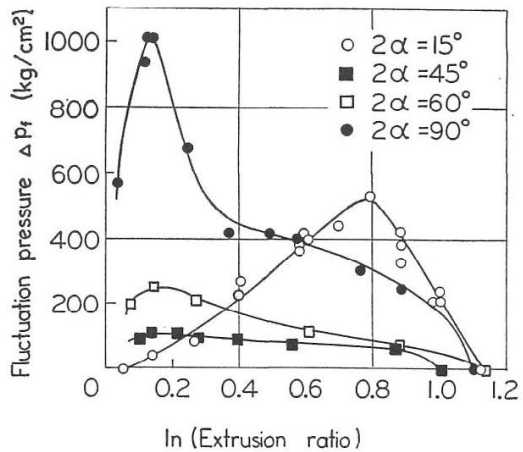

Fig. 6. Effects of die angle $\alpha$ and extrusion ratio on fluctuation pressure $\Delta p_{f}$.

$2 \alpha=90^{\circ}$ と $15^{\circ}$ の両者に批いて著しい. $2 \alpha=30^{\circ}$ の值

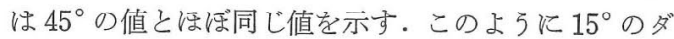
イではっきりしたステイックスリップを起こすのは $\mathrm{AC} 2 \mathrm{~B}$ のみであり, 他の材料はバルジ变形を起こす $90^{\circ}$ ダイのときのみにステイックスリップを起こして いる.ただ潤滑剤との化学反応性が恵い同じアルミニ ウム系の A 1B 1 も15のダイでステイックスリップを 起こすが，ステイックスリップの形態は $\mathrm{AC} 2 \mathrm{~B}$ の場合 と異なって和り，A1B1 は非常に短い周期で振動し $\Delta p_{f}$ ठ小さい。

\section{$3 \cdot 4$ 押出し材表面のミクロプロフィル}

Fig. 7 Kステイックスリップが起きたときの押出し 材表面のミクロプロフィルを示す。西らさの測定位置 は，Fig. 7 に示すようにダイ円錐部分 $\mathrm{A}$ と押出された 部分Bであり押出し方向に測定した。Fig. 7 の(a)上り 変形の進行につ机て素材のあらさがダイとの接触面で 平担化されていくのがわかる。このことから出口近傍 では, 厚い潤滑膜は存在し得なくて境界潤滑状態每 ると考兄られる。このことは，押出された材料が金属 光沢を有していることからも推察される。一方 Fig. 7 の(b)に示すように押出さ机た部分には，ステイックス リップの影響として外表面に円環状のストップマーク ができているが，この数は押出し線図に現われている 振動の山数と一致している. AC2B の押出された部分 の表面あらさは，ダイ角度，押出し比に上る変化は莗
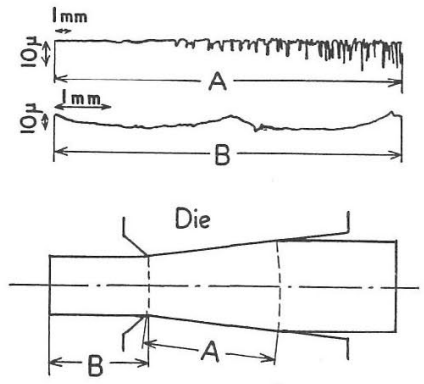

Fig. 7. Micro-profiles of extruded billet ( $2 \alpha=$ $15, \mathrm{AC} 2 \mathrm{~B}, R=2.2$ ). 
まり認められなかった。しかし，ダイに接している部 分の表面あらさは, 押出し比が大きくなると全接触部 分にわたって平担化されている，ただ，ダイ角度が小 さい場合はダイ角度が大きい場合よりも多少平担化さ れる割合が小さくなっている。これはダイ角度が小さ いとくさび効果によって潤滑剤ががイとビレット間に 入り込みやすくなるためであると考兄られる。

\section{4 検 討}

ここではまず押出し荷重が自由振動を行ならこと について述べ, 次飞供試材料拈よび潤滑剂がステイッ クスリップにおよぼす影響について検討する。さらに， バルジ変形に起因するステイックスリップについて若 干の検討を加苀る。

\section{$4 \cdot 1$ 押出し圧力の自由振動}

Fig. 8 は静水圧押出しの概念図である.プランジヤ 飞負荷するとビレットは圧力媒体液を介して押出され る. Fig. 9 はFig. 3(b)の圧力変動を電磁オッシログラ フで描かせたものである.ビレットの運動着目する と,ビレットはA点で急激にすべり始め, A B 間です ベり， B 点で再びダイと固着し， B C 間固着している. 次に, 压力媒体液のエネルギ着目すると, ビレット がダイに固着している間もプランジャは前進して圧力 媒体液を圧縮するので, その間圧力媒体液中にェネル ギが蓄積されているが，この蓄積された力がビレット をダイに固着させている力よりも大きくなると、ビレ ットはすべり始めるはずである。つまり，Fig. 9 亿示 したステイックスリップは自励振動の一種であり，エ ネルギが蓄積される過程と蓄積されたエネルギを消費 される過程が存在し，固着している期間とすべってい る期間がそれらに対応している。

Fig. 8 亿示した静水圧押出しの運動を Fig. 10 亿示 すような単純化したモデル㯰き換えて考光るとA B

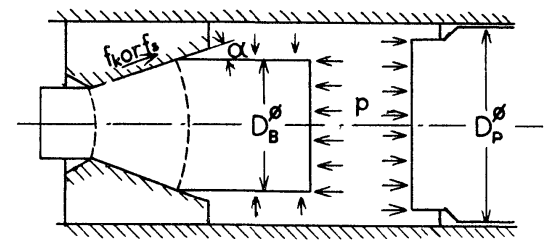

F1g. 8. General view of hydrostatic extrusion.

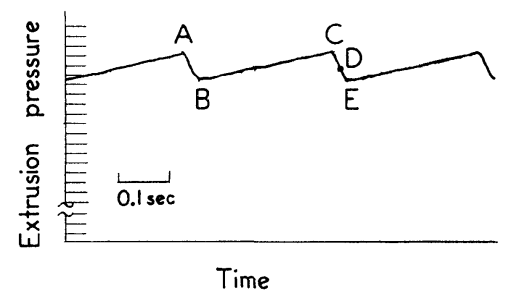

Fig. 9. Pressure varıation in stick-slip motion.

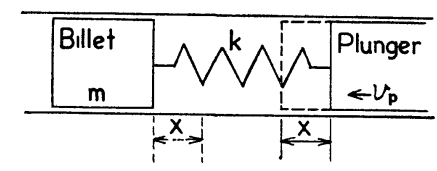

Fig. 10. A model of stick-slip motion under hydrostatic extrusion.

間の運動はすべり面に磨擦力が働く単振動の問題とし て取り扱らことができる。 ここでビレットとダイの静 摩擦力と動摩擦力をそれぞれ $f_{s}, f_{k}$ としビレットは バネ作用する力が $f_{s}$ に等しくなったときにすべり 始め,すべっている間の摩擦力は一定であると仮定し, バネの圧縮量を $x$ とすると, ビレットの運動方程式は

$$
m \frac{d^{2} x}{d t}-f_{k}=-k x
$$

で与えられる、ここで, 初期条件として, すべり始め の点を考光ると，A点に和ける変位は $x=f_{2} / k$ であり， その時の速度はプランジャの加圧速度 $v_{p}$ に等しいの で(1)式の解は

$$
x(t)=\frac{f_{s}-f_{k}}{k} \cos w t+\frac{f_{k}}{k}+\frac{v_{p}}{w} \sin w t
$$

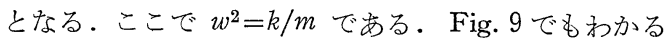
ように $v_{p} / w$ はきわめて小さいので, 最後の項は省略 できて，

$$
x(t)=\frac{1}{k}\left\{\left(f_{s}-f_{k}\right) \cos w t+f_{k}\right\}
$$

と書ける。つまり $d x / d t=v_{p}$ のとさすなおち $w t=\pi$ のとき, ビレットは再びダイに固着すると考えてよい， な挍, 静水圧押出しに捻いては, プランジャとビレッ 卜間の相対変位量 $x$ とプランジャ荷重との間には, 高 圧域においては（たと光ば $\mathrm{AC} 2 \mathrm{~B}$ の場合, 押出し比が 約 1.8 のときの定常押出し圧力は約 2400 気圧) 湾湆直 線関係がなりたつので, ビレットが第(3)式で示される ような間欠運動を行な 5 と, 押出乙压が周期的飞振動 すると考光らる。

ここでは, 単純化したモデルで押出し圧力の変動を 説明したが，このモデルでは，Fig. 11 に示すステイ ックスリップの発生初期の現象㐨よび Fig. 12 亿示す ようなステイックスリップが消滅する限界押出し比近 傍で起こる定常押出し後期のステイックスリップは説 明できない，この大きな理由として(1)ダイとビレット 間で発生する熱の潤滑油膜に拉よ湆す影響を無視した こと，(2)第(1)式で減衰項 $d x / d t$ を考慮しなかったこと

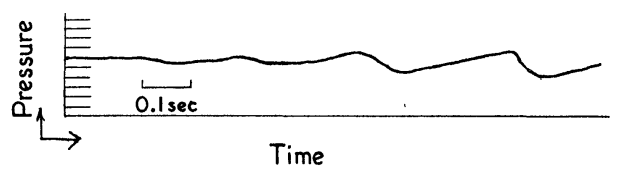

Fig. 11. Showing start of stick-slip motion by an electromagnetic osc1llograph. 


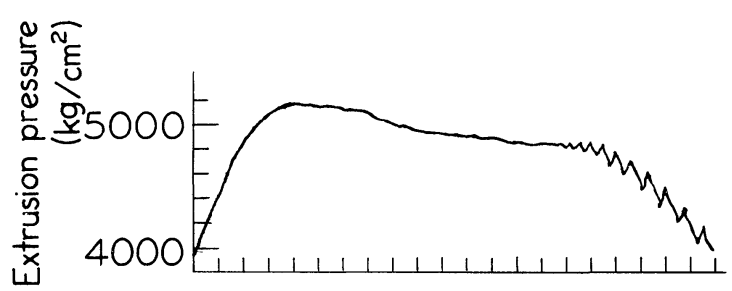

Plunger stroke

Fig. 12. Pressure diagram for $\mathrm{AC} 2 \mathrm{~B}$ showing stick-slip motion near the critical extrusion ratio stick-slip motion is extinct $(2 \alpha=15, \mathrm{AC} 2 \mathrm{~B}, R=4.5)$.

が考光られる。たと党ば，Fig. 11 飞示す発生初期の 現象は, ダイとビレット間に存在する潤滑油膜の厚さ 特よび強度は急激に変化できず, 徐々汇变化しながら 一定值に近づくためであると考兄られる。

\section{$4 \cdot 2$ ダイ面の摩擦係数の変化}

Fig. 9 亿括いてA点㧊よびC 点は静摩擦時の押出し 状態に相当し, 一方, すべりの中央点 D が動摩擦時の 押出し状態に相当する.

軸対称押出しの際のビレットとダイ表面の摩擦係数 を知る方法としては, 初等解による方法や, 半径方向 流れを用いた上界接近法が知られているが，初等解の 近似解法と上界法から得られる $\Delta \mu$ は両者之も次式で 表わされる。

$$
\Delta \mu=\mu_{s}-\mu_{k}=\left\{\frac{\left(p_{s}-p_{k}\right)}{Y_{m}}\right\} \times \frac{1}{\varepsilon \cdot\left(1+\frac{\varepsilon}{2}\right) \cot \alpha}
$$

ここで $p_{s}$ は静摩擦のときの押出し圧力, $p_{k}$ は動摩擦 のときの押出し圧力, $\varepsilon=\ln R$ である. な执, 平均変 形抵抗 $Y_{m}$ は定常押出し圧力之压縮試験で得られた $Y(\varepsilon)$ 曲線を用いて次式から求めた。

$$
\left.\begin{array}{rl}
p_{e} & =\int_{0}^{\varepsilon} Y(\varepsilon) d \varepsilon \\
Y_{m} & =\left[\int_{0}^{\varepsilon} Y(\varepsilon) d \varepsilon\right] / \varepsilon
\end{array}\right\}
$$

(4)式から，ダイ半角が小さい時汪ど，末た変形抵抗之 押出し比が大きい汪ど， $\Delta \mu$ のわずかな変化に対して $\Delta p_{f}$ は大きく変化することがわかる．Fig. 13 は大き なステイックスリップが起こる $\mathrm{AC} 2 \mathrm{~B}$ を $2 \alpha=15^{\circ}$ の

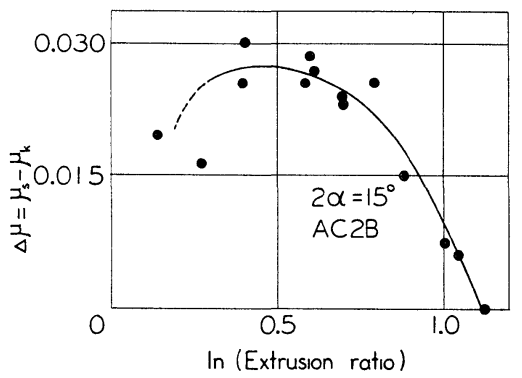

Fig. 13. Effects of extrusion ratio on $\Delta \mu$ calculated by Eq. (4).
がイで押出したときの $\Delta \mu$ と押出し比の関係を示し たものである。このように，小さな $\Delta \mu$ の変化が大 きな圧力変動を引き起こすが (Fig. 6 の白丸)， $\Delta \mu$ がなや゙押出し比によって変化するのかは今のところ わからない。

$4 \cdot 3$ ダイとビレット界面の潤滑油膜におよばす 温度の影響

$\mathrm{AC} 2 \mathrm{~B}$ は $2 \alpha=15^{\circ}$ のダイで押出す場合，押出し 比が 3 以上だと室温で押出した場合は定常押出し中 にはステイックスリップを起こさない。しかし，ダ イおよびビレットを加熱して押出しを行なうとFig.14 に示すようにステイックスリップを起こす．温度が低 くなるにしたがってステイックスリップが起こる時期 は遅くなり，また $\Delta p_{f}$ もささくなっている。このこ とから, ダイとビレット間に存在する潤滑油膜の変化, 特に温度による変化が静水圧押出しに和けるステイッ クスリップと樑い関連があると思われる。

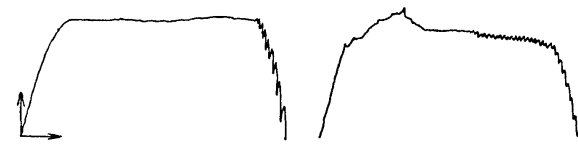

(a) Room temperaure $t=13^{\circ} \mathrm{C}$

(b) $t=45^{\circ} \mathrm{C}$

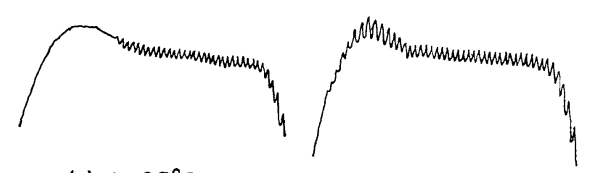

(c) $t=65^{\circ} \mathrm{C}$

(d) $t=100^{\circ} \mathrm{C}$

Fig. 14. Effects of heating temperature on stick-slip motion $(2 \alpha=15, \mathrm{AC} 2 \mathrm{~B}, R=3)$.

\section{$4 \cdot 4$ 供試材料之潤滑剂の影響}

Fig. 15 は泳ぼ同じ硬度と変形抵抗を有する $\mathrm{Zn}$ $\mathrm{ADC1}(\mathrm{Hv}$ 94.2) と $\mathrm{AC} 2 \mathrm{~B}(\mathrm{Hv}$ 93.5) を摩擦熔接 法で接合して押出したもので, 前部が $\mathrm{ZnADC1}$, 後部

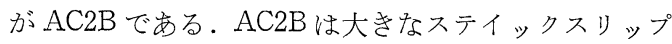
を起こすが，ZnADC1 は全然起こらない材料である。 なお，この場合の動摩擦係数を上界法で求めるとそれ ぞれ0.03，および 0.033 となる。亦た押出された表面

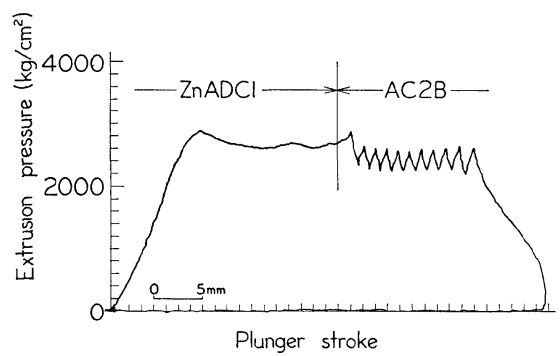

F1g. 15. Pressure diagram for $\mathrm{ZnADCl}$ and $\mathrm{AC2B}$ $(2 \alpha=15, \quad R=1.79)$. 
はいずれも滑らかで平均あらさは $H_{\max }$ で約 $2 \mu$ であ る。

潤滑の研究に上れば，接触する二種の金属間に括け る $\mu_{s}<\mu_{k}$ は金属の組み合わせ依存する。一方， Rabinowicz はこの特性に対して，すべり速度は非常 に大きな影響を与光るが，面のあらさや荷重は無関係 であると説明している。もとも滑らかな運動 $\left(\mu_{s}=\right.$ $\mu_{k}$ ）に対しては速度の影響もない，そこで，潤滑され た状態に拈いて，AC2B でステイックスリップがあら われ，ZnADC1 でステイックスリップがあらわ礼な いのは，潤滑剤と金属の反応性とすべり速度が考兄ら れる、 $\mathrm{AC} 2 \mathrm{~B}$ も押出し速度がきわめて遅いとステイッ クスリップを生じない。

次に Fig. 16 に示すよ5に AC2B 亿対する二硫化モ リブデンおよび黒鉛潤滑剤の効果が大きいのは，層状 組織をもつこれらの潤滑剤がダイとビレット間に入り 达んで, 高温まで安定な潤滑油膜を形成するためであ ろう． $90^{\circ}$ ダイでは潤滑剤の効果がないのに, $15^{\circ}$ ダ イでは添加潤滑剂の効果が大きいのは， $\alpha$ が小さいた わにくさび効果によって潤滑剂がダイとビレット間に 入り込み易いためである。

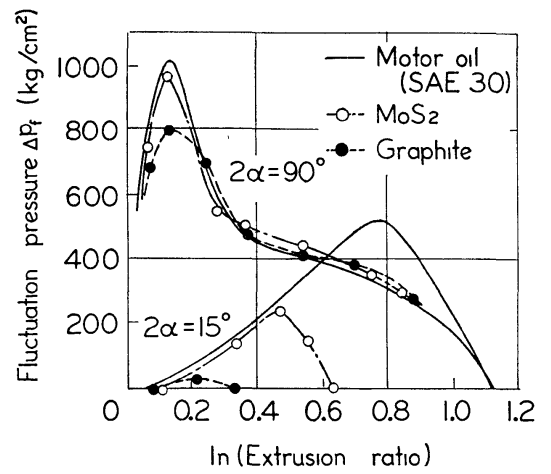

Fig. 16. Effects of lubricants on stick-slip motion for $\mathrm{AC} 2 \mathrm{~B}$.

AC2B を溶体化処理をした場合 (Hv 123)，15ダ イでステイックスリップは起こらなかった。しかし， 溶体化処理後外表面を削り取って押出すと，ステイッ クスリップが起こった。これは，AC2B を熱処理した 結果生じた酸化膜層と,ささら地金のかたさも増すこ とによって，酸化膜が変形時汇破壊されず，ダイとの 凝着が起こりにくくなるためであろう。つまり，酸化 膜と地金の硬度差が大きく機械的性質の異なるもの添 ぞ，接触部が塑性変形を受けるとき，酸化膜がその変 形に追従しきれず破壊するので容易汇凝着が起こるこ とが知られている。

$4 \cdot 5$ バルジ変形に起因するスティックスリップ 押出し比が小さい範囲で起こる材料の盛り上りを伴 万押出しの恋形模様は，くさびの押込夕や負のすくい

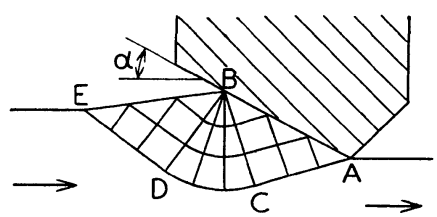

F1g. 17. Postulated slip line field for very small reductions of area.

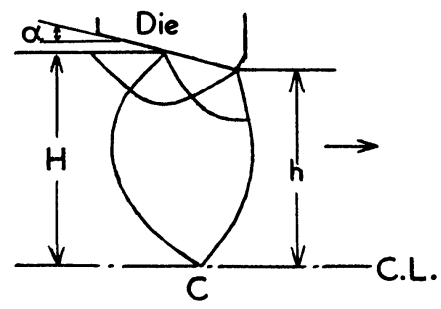

Fig. 18. Slip line field for limit of buldge formation.

角をもつ切削変形と対比して考兄られる. 押出し比が 小さいとダイ面圧は非常に大きくなり，この場合には Fig. 17 に示すようにダイは圧子のような作用をして， ダイ入口側で材料の盛り上がりが起こる。この場合, 変形域は表面近傍飞限られ，材料表面飞 standing一 wave が生じるが，押出し比がある值に達すると， Fig. 18 に示すように材料の盛り上りはなくなり，す ベり線場がブロックを貫通する。このバルジが消隇す るバルジ限界の断面減少率 $r_{B}$ は平面すべり線場から

$$
r_{B}=\frac{H-h}{H}=\alpha\left(0.23+\frac{\alpha}{9}\right)
$$

として与兄られる。ここで, 平面ひずみ線場の解を軸 対称押出しに適用する方法として(1)押出し比を揃兄る 方法と，(2)ダイプロフィルを揃える方法の二つが考克 られるが，対応法(1)を用いて， $2 \alpha=90^{\circ}$ に対するバル シ限界押出し比 $R_{B}$ を(6)式上り求めると, $R_{B}=1.325$ $\left(\ln R_{B}=0.282\right)$ となり, Fig. 4 の限界押出し比とよく 一致する。また，ダイ代るバルシの残与物拈よび押 出し材の観察結果から判断すると, 対応法(1)を用いて 求めた $R_{B}$ は有効であると考穴られる。このよ5に， バルジ限界押出し比とステイックスリップの消隇する 押出し比が良い一致をみることから，バルジ変形とス テイックスリップには深い関連があるとい克る。

バルシ変形に起因するステイックスリップの場合は 材料の盛り上りにつれてダイ面での摩擦力が増大して その間に圧力媒体液中に貯光られたポテンシャルエネ ルギがある值に達すると急にすべりが起こっている． この過程は, 先に述べた境界潤滑状態での自励振動と 同じであるが，バルジ変形に起因するステイックスリ ップの場合は，押出された材料表面に周期的なむしれ 傷が生じて拈り，材料内部ですべりが起こっているこ とを示している (Fig. 5). Fig. 19 は，ダイ入口手前 


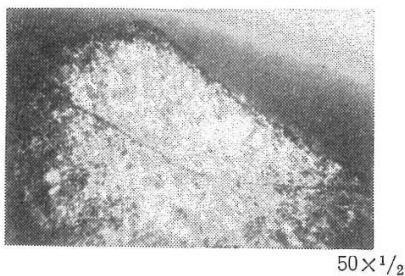

Fig. 19. Crack of buldged zone $\left(2 \alpha=90^{\circ}, \mathrm{ZnADCl}\right)$.

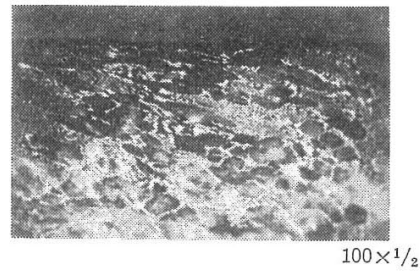

Fig. 20. Showing heavy shearing of slip zone $\left(2 \alpha=90^{\circ}, \mathrm{ZnADCl}\right)$.

に特ける材料の盛り上りとそこに発生しているき裂を 示す例である。材料が急速にすべっている状態を具現 することは不可能であるので，この写真は固着終点近 傍で押出乙を中止して断面の検鏡を行なったるのでめ る。さ裂の様子は Fig. 17 のすべり線場に和子る線 A -C-D-E K似ている．Fig. 20 は，はげしくもし られた個所を検鏡した写真であり，表面層近くでのみ 大きな材料の流れが起きているのが明らかである。以 上の観察結果から，材料がバルジ変形を起こした後急 激にすべる場合は，ダイとの間ですべるのではなくて， これよりも変形ェネルギの小さい材料内部で急激なせ え断変形を起こするのと考光られる。气してこのむし れを生じる時のせん断変形力が $f_{s}$ に比べて小さいため にステイックスリップを起こすと考完られる。ところ で，材料によってむしれを生じるものと生じないるの とにわかれるが，これは材料の破壞ひずみが小さけれ ばダイ面ですべるよりも材料内部でせん断すべりを起 こした方が変形に要するエネルギが小さくて済み, 破 壤ひずタが大きければ，むしれを起こすよりも stand ing-wave を起こしてダイとの間ですべった方がエネ ルギが小さいためであるう。

\section{5 結論}

静水圧押出しの際に発生するステイックスリップを 防止するの学目的として, ダイ角度, 押出し比, 素材, 潤滑剤の影響について調らべた結果次のことがわかっ た。

（1）潤滑剤との反応性が悪い材料はステイックスリ
ップを起こし易いが，ダイとビレット間の温度が高く なると,ダイとビレット間の潤滑油膜が薄くなって大 きなステイックスリップが起こるよ5になる。

（2）静水圧押山にしおけるステイックスリップは閏 滑剂の影響が大きい。特にダイ角度が小さいと，くさ び効果に上って潤滑剂がダイとビレット間に入り込多 やすくなり，ステイックスリップが防止できる。

（3）金属の組合せ飞よる $\Delta \mu$ がない材料でもバルジ 変形を起こす場合は，材料の延性が息しいと材料内で 急激なせん断すべりが起こるので激しいステイックス リップが起こる。一方延性が充分㐫る材料は， standing-wave 它生じて多形するので，六ティックスリッ プは生じない。

終わりに，本実験をてつだっていただいた豊田工機， 土屋幸治氏扣よび三菱商事，古橋明広氏謝意を表す る。また，有益な助言をいただいた京都大学大矢根教 授はじめ研究室の諸氏に感謝する。

（炤和46年1月29日高圧を利用した塑性加工シンポジウムにて講演）

\section{参考文 献}

1) Pugh, H.L1.D., and K. Ashcroft. "Symp. on the Physics and Chemistry of High Pressure”, 163 (1963) Society of the Chemical Industry, London.

2) Fiorentino, R. J., et al., Intern. Conf. Mfg. Technol, 941 (1967).

3）松浦祐次他 2 名, 第21回塑性加工連合講演会論文集, 219 (1970).

4）西原正夫ほか 4 名, 同上, 231，239.

5) Bowden, F. P., and D. Tabor, "The Friction and Lubrication of Solids. Part II”, p. 78 (1964) Oxford at the Clarender Press.

6) Rabinowicz, E., "Friction and Wear of Materials," p. 52 (1965) John Wiley and Sons, New York.

7) 工藤英明ほか 3 名, 機械学会誌, 67一-542，392 (1964).

8) Dudley, B.R., and H.W. Swift, Phil. Mag., 40. 849 (1949).

9）バウデン，テイバー，“固体の摩擦と潤滑”, 曽田範宗訳, 第 5 章 (1961) 丸普

10) Avitzur, B., Trans. ASME, (B) 86, 305 (1964).

11) Pugh, H. L1. D., NEL Report, No. 142, 24 (1964).

12）工藤英明他 2 名, 塑性と加工，6一56，499 (1965).

13) Hill, S. J., Tupper, J. Iron and Steel. Inst., 159, 353 (1948).

14) Green, A. P., and R. Hill, J. Mech. Phys. Solids, 1, 31 (1952-53). 